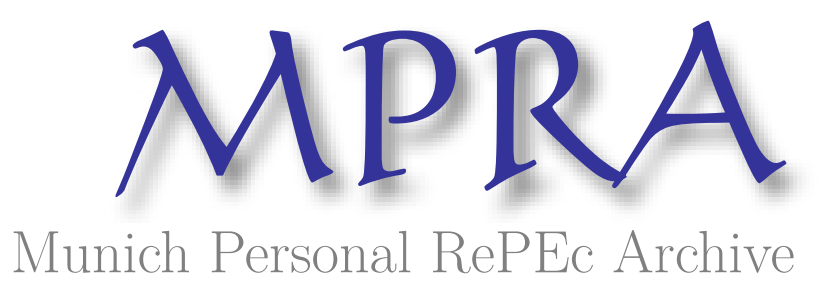

\title{
Central Banks' responses to the Covid-19 pandemic: The case of the Bank of Central African States
}

Asongu, Simplice and Ojong, Nathanael and Soumtang,

Valentine

August 2021

Online at https://mpra.ub.uni-muenchen.de/111558/

MPRA Paper No. 111558, posted 16 Jan 2022 08:24 UTC 


\title{
$\underline{\text { A G D I Working Paper }}$
}

\author{
$\mathrm{WP} / 21 / 076$
}

\section{Central Banks' responses to the Covid-19 pandemic: The case of the Bank of Central African States}

\author{
Simplice A. Asongu \\ African Governance and Development Institute, \\ P.O. Box: 8413, Yaoundé, Cameroon. \\ E-mail: asongusimplice@yahoo.com/asongus@afridev.org \\ Nathanael Ojong \\ International Development Studies, \\ 324 Founders College, York University \\ 4700 Keele Street Toronto, ON M3J 1P3, Canada \\ E-mail: nojong@yorku.ca \\ Valentine B.Soumtang \\ Faculty of Economics and Management, \\ University of Yaoundé II, Cameroon. \\ E-mail: valentinebime@yahoo.com
}


Research Department

\title{
Central Banks' responses to the Covid-19 pandemic: The case of the Bank of Central African States
}

\section{Simplice A. Asongu, Nathanael Ojong \& Valentine B. Soumtang}

\author{
August 2021
}

\begin{abstract}
This study explores the responses to the COVID-19 pandemic by the Bank of Central African States (BEAC), which is the central bank for countries in the Central African Economic and Monetary Community (CEMAC), that is, Cameroon, Chad, Gabon, Equatorial Guinea, Central African Republic, and the Republic of Congo. While hitherto, BEAC had fundamentally focused on fighting inflation and promoting monetary integration and financial stability in its member states, the COVID-19 pandemic, among other factors, has motivated it to also shift its policies towards targeted credit programmes and more economic growth. This study sheds light on four core aspects: (i) the socio-economic context of the CEMAC region prior to the COVID-19 pandemic, (ii) BEAC as a lender of last resort, (iii) historical, contemporary, and future insights surrounding targeted credit programmes, and (iv), suggestions for the path forward in terms of reforms, with emphasis on inclusive growth and monitoring economic development at the regional level.
\end{abstract}

Keywords: Covid-19 pandemic; monetary policy; central bank responses; CEMAC, BEAC 


\section{Introduction}

Globally, the Covid-19 pandemic has simultaneously affected demand, supply, and financial conditions, prompting central banks to react using diverse measures in order to tackle the adverse economic impact of the pandemic. While much has been documented regarding the responses of central banks to the COVID-19 pandemic, most of the existing literature has been skewed toward developed countries (Mosser, 2020; Elgin, Yalaman, Yasar \& Basbug, 2021). Two reasons can explain this tendency for sparse scholarship on Africa: (i) most countries in Africa do not have the relevant instruments for monetary policy effectiveness (Asongu, 2014), and (ii) some countries, especially former French colonies, have sacrificed monetary experience for monetary stability, and by extension, monetary dependence on the former colonial power (Joseph, 1976; Asongu, 2016). In the postcolonial era, non-French-speaking countries largely abandoned their colonial monetary designs and created a national central bank, which contrasts with former French colonies that mostly maintained their colonial monetary arrangements and structures, which connected them to neighbouring countries in a multilateral architecture as well as to France (Abdel-Salam, 1970; Masson\& Pattillo, 2004; Vinay, 1988). This is precisely the case of countries in the Central African Economic and Monetary Community (CEMAC) that is, Cameroon, Gabon, Chad, Equatorial Guinea, Central Africa Republic, and the Republic of Congo. ${ }^{1}$ These six countries share a common central bank - the Bank of Central African States (BEAC) - and they use the CFA franc issued the central bank.

The aim of this study is to explore the BEAC's responses to the COVID-19 pandemic. Two principal reasons drive the study of the BEAC's responses to the COVID-19 pandemic. First, consistent with Mosser (2020), it is too early to establish how the actions of central banks have affected the real economy and hence the role of the central banks in easing financial conditions in view of addressing socio-economic concerns, not least because these are yet not fully documented in the literature. Second, the present study complements the scholarship on this issue in Africa, especially as the extant African-centric studies on the issue have largely focused on selected English-speaking countries, including Nigeria (Ejiogu, Okechukwu \& Ejiogu, 2020), Ghana (Dzigbede \& Pathak,2020), and South Africa (Nchanji et al., 2021), among others.

The rest of the study is structured as follows. Section 2 discusses the socio-economic context of the CEMAC region prior to the COVID-19 pandemic, while Section 3 examines

\footnotetext{
${ }^{1}$ It should be noted that Equatorial Guinea was formerly a colony of Spain. Equatorial Guinea joined the Central African currency zone in 1985.
} 
the BEAC as a lender of last resort. In Section 4, historical, contemporary, and future insights surrounding targeted credits are discussed, while Section 5 provides suggestions for the path forward. Section 6 concludes with a summary of the study and directions for future research.

\section{Pre-COVID-19 socio-economic context of CEMAC region}

Before examining the BEAC's responses to the COVID-19 pandemic, it is vital to set the stage by shedding light on the pre-COVID-19 socio-economic context in the six countries that constitute the CEMAC region, and therefore this is provided here. Providing this socioeconomic background is important as it ensures a better understanding with respect to the measures adopted by the BEAC.

Cameroon is the largest economy in the CEMAC region, and its economy grew an estimated $4.1 \%$ in 2019; however, economic growth in Cameroon has been hampered by unrest in the north- and south western regions of the country (IMF, 2019). In the Central African Republic, real GDP growth increased from 3.8\% in2018 to 4.5\% in 2019, while in Chad, after two years of recession (2016 and 2017) following the drop in the price of oil, real GDP growth turned positive, reaching 2.4\% in 2019 (African Development Bank [AfDB], 2020).Gabon recorded an estimated real GDP growth of $3.4 \%$ in 2019, with the Republic of Congo at $2.2 \%$ that year, while Equatorial Guinea's real GDP is estimated to have shrunk by $4.1 \%$ in 2019 after a contraction of $6.1 \%$ in 2018 , as the country sought to emerge from an economic recession caused by the 2014 slump in oil prices (AfDB, 2020).Figure 1 depicts the variations in real GDP growth in the CEMAC region from 2014 to 2019.

Figure 1: Real GDP growth (annual percentage change)

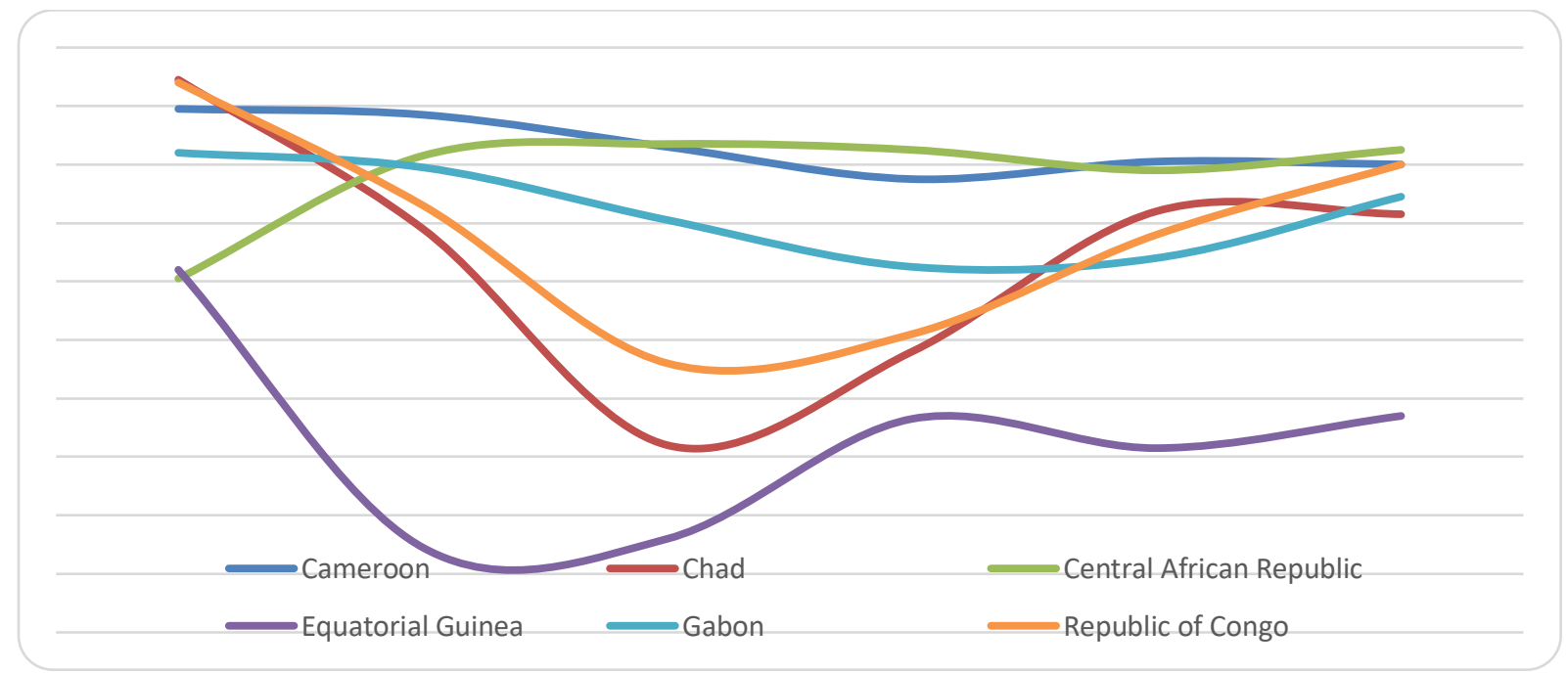

Source: Data obtained from United Nations' World Population Prospects 
CEMAC economies rely heavily on oil, which is their main export commodity. In Chad, for example, 79\% of export revenues came from oil in 2019 (AfDB, 2020). However, other sectors also play an important role in these economies. In Chad, agriculture accounted for almost $35 \%$ of GDP in 2019, employing $75-80 \%$ of the population (AfDB, 2020), whereas in Equatorial Guinea, between 2014 and 2018, the agricultural sector's contribution to the national economy was less than $2 \%$ (AfDB, 2020).

From 2018 to 2019, the inflation rates in Cameroon, Central Africa Republic, and the Republic of Congo rose from $1.1 \%$ to $2.4 \%, 1.6 \%$ to $3.5 \%$, and $1.2 \%$ to $1.8 \%$, respectively (AfDB, 2020). In Chad, the inflation rate was 3\% in 2019, while in Equatorial Guinea it increased slightly from $1.3 \%$ in 2018 to $1.4 \%$ in 2019 , with a reverse trend being recorded in Gabon, where it decreased from $4.8 \%$ to $3.4 \%$ during the same timeframe (AfDB, 2020).

Following debt relief, the external public debt of the CEMAC region increased rapidly. It should be noted that Central African Republic, Cameroon, and the Republic of Congo particularly benefited from significant debt relief after reaching their Highly-Indebted Poor Country completion points. Gabon's debt decreased substantially due to debt restructuring in 2007, and Chad's debt profile also improved following debt relief of US\$1.1 billion in April 2015 (de Zamaroczy et al., 2018). In 2017, the Republic of Congo had a debt-to-GDP ratio of 95.7\% (AfDB, 2018), and this decreased to 88\% in 2019 (AfDB, 2020). In a similar vein, Gabon's debt-to-GDP ratio decreased slightly from $60.6 \%$ in 2018 to $58.7 \%$ in 2019 (AfDB, 2021). The Central African Republic's debt-to-GDP ratio dropped from $48.5 \%$ in 2018 to $42.2 \%$ in 2019 (AfDB, 2020), while that of Chad decreased slightly from $25.6 \%$ in 2018 to $24.2 \%$ in 2019 (IMF, 2020). Cameroon's debt-to-GDP ratio was about 39\% in 2018 (AfDB, 2020), while for Equatorial Guinea, it was $41.1 \%$ in 2019, a steep rise from $12.6 \%$ in 2014 (AfDB, 2021). Clearly, the debt-to-GDP ratio varies among countries in the region.

There were also variations in current accounts in the region. Gabon's and Chad's current account deficits deepened from $2.3 \%$ in 2018 to $3.2 \%$ in 2019 and from $3.4 \%$ in 2018 to $6.7 \%$ of GDP in 2019, respectively (AfDB, 2020), but in contrast, the Central African Republic and Equatorial Guinea experienced a decline in their current account deficits, from $8.3 \%$ of GDP in 2018 to $5.2 \%$ in 2019 and $7.7 \%$ in 2018 to $5.6 \%$ in 2019, respectively. Finally, Cameroon's current account deficit remained at the same level for 2018 and 2019 (i.e., 3.7\% of GDP), while the Republic of Congo recorded a current account surplus of $8 \%$ of GDP in 2019, up from 6.7\% in 2018 (AfDB, 2020). 
Countries in the CEMAC region are quite diverse in terms of fiscal balances. For example, Cameroon's fiscal deficit declined from 2.5\% of GDP in 2018 to $2.3 \%$ in 2019, while in the Central African Republic, the fiscal balance was in surplus in 2019 (i.e., 2.4\% of GDP compared to $0.4 \%$ in 2018), but in the Republic of Congo, it increased to $8.8 \%$ of GDP in 2019 from 6.8\% in 2018 (AfDB, 2020). Stabilisation was seen in Chad, which produced a balanced budget both in 2018 (1.9\% of GDP) and 2019 (0.2\%), and Equatorial Guinea also produced a balanced budget in 2018 (0.5\% of GDP) and 2019 (1.3\%) (AfDB, 2020).

Based on estimates by the World Bank (2021a), the number of people living in poverty in Chad increased from 4.7 million to 6.3 million between 2011 and 2019. Even more grimly, Chad ranked 187thout of 189 countries on the Human Development Index, with youth unemployment at 60\% in 2017 (AfBD, 2020). According to Cameroon's National Institute of Statistics (NIS) (2015a), about 37.5\% of the population lives below the national poverty line of 931 FCFA (US\$1.5) per day. ${ }^{2}$ The World Bank notes that the number of poor people in Cameroon increased by $12 \%$ to about 8 million between 2007 and 2014 (World Bank, 2021b), with unemployment among those aged between 15 and 35 being recorded at about 13\%, but crucially, underemployment has been recorded at $71.9 \%$ at the national level, and $54.4 \%$ and $79.2 \%$ in urban and rural zones, respectively (AfDB, 2012). As of 2015, informal employment stood at $88.6 \%$ (NIS, 2015b).The Central African Republic ranked second to last in the 2019 Human Development Index, with around 62\% of the country's population estimated to be living in poverty in 2018 (WFP, 2018). As for Equatorial Guinea, 70\% of its population lived in poverty in 2018 (UNFPA, 2018), and about 25\% of the working age population was unemployed in 2017 (AfDB, 2020).A third of Gabon's population lived below the poverty line in 2018 (IMF, 2019), while $40.9 \%$ of the population in the Republic of Congo lived in poverty in 2019 (AfDB, 2020), with about 40.5\% of youths being unemployed (ILO, 2016).

Clearly, the socio-economic situation of the six countries which constitute the CEMAC region was quite diverse prior to the start of the COVID-19 pandemic. Following the outbreak of the pandemic, the BEAC implemented different measures to mitigate the adverse economic impact of the pandemic in these six countries. In the next section, we examine the BEAC's role as a lender of last resort.

\footnotetext{
${ }^{2}$ The conversion rate used throughout this study is $1 \mathrm{US} \$=588.5$ FCFA (Franc Communauté Financière
} Africaine). 


\section{BEAC as a lender of last resort}

Given the magnitude of the economic impact of the COVID-19 pandemic and the unique nature of this crisis, several central banks, mostly in developing countries, have put in place exceptional direct intervention mechanisms that go beyond traditional monetary easing measures. In the CEMAC region, the BEAC, in its capacity as lender of last resort for the region, as of March 2020, adopted a series of important measures through its Monetary Policy Committee (MPC) that were aimed at sustaining bank liquidity, but also had a direct impact on the financing conditions of governments, the public securities market, and the production sector. These strategies included the resumption of active injections and the lowering of the BEAC's main interest rates, reorganization of the conditions for eligibility for guarantees for the BEAC refinancing operations, and the implementation of a programme to buy back government securities on the secondary market.

With respect to the first strategy, several measures were taken. The context of uncertainty surrounding COVID-19 led the central bank to increase the weekly volume of liquidity injected into the money market to 250 billion FCFA, whereas liquidity withdrawals had been capped at 36 billion FCFA before the crisis began (BEAC, 2020g). This increase was mainly intended to assure the production sector and credit institutions of the BEAC's readiness to reduce liquidity risk in the money market. However, the effects of this measure were mixed. Indeed, in general, the subscription rate remained relatively low (around 25.62\%) until the end of 2020 before rising again at the beginning of 2021(BEAC, 2021b), as illustrated in Figure 2.

Figure 2: Evolution of commercial banks' needs at BEAC in billions

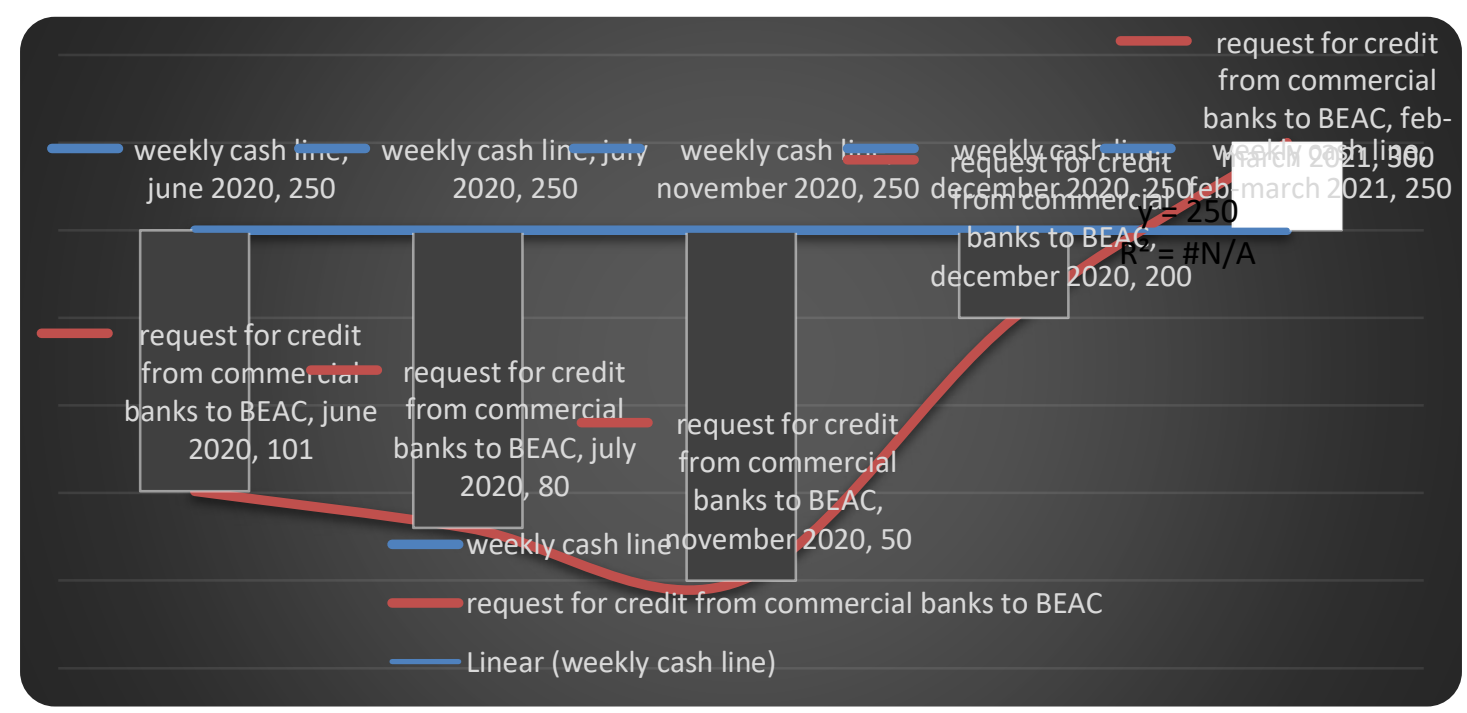


Source: BEAC, COBAC, 2020-2021; based on TIAO subscriptions

An analysis of Cerber ${ }^{3}$ data also highlights this progression. Indeed, the share of loans granted to the private sector in the sub-region has been declining since the crisis before rising by about $8.34 \%$ over the period July 2020 to June 2021, to reach a grand total of 98.057 billion FCFA as of July 1, 2021 (COBAC, 2021) .

Furthermore, following the fall in crude oil prices in the CEMAC region, the BEAC's MPC also decided to lower the marginal lending rate by 100 points, from $6 \%$ to $5 \%{ }^{5}$, and the interest rate on tenders by 25 points, from $3.5 \%$ to $3.25 \%$ (BEAC, 2020b). This measure has resulted in a marginal increase in the weighted average allocation rate to $3.34 \%$ since September 2020. The injection strategy was also accompanied by an upward revision of the amount of liquidity to be injected into the money market to 500 billion FCFA. In fact, in a second decision in 2020, the MPC increased the amount of liquidity injections on the money market from 240 billion to 500 billion FCFA, and has committed to increasing this amount if necessary.

The second strategy adopted by the BEAC mainly focused on the modification of the status of the discounts applicable to public securities issued in the CEMAC. In fact, two decisions were taken to make this change. First, the MPC suspended any upward revision of the discounts applicable to public securities used as collateral for monetary operations. Second, it decided to lower all these discounts uniformly by 800 basis points after June 2020 (BEAC, 2020c; BEAC, 2020d). These changes remained valid until August 2021(BEAC, 2021a).

This reorganization of the eligibility conditions for guarantees for the BEAC refinancing operations led to an increase of more than 238.4 billion FCFA in advances available from public collateral. This increase in refinancing options for credit institutions concerned all counterparties holding public securities. In addition, although the proportion of private claims in the collateral stock of credit institutions remains low, the MPC measures have contributed to the increase in the lending facilities of the institutions by almost 22.9 billion FCFA in connection with the classification agreements issued on credit granted to the private sector. As of November 30, 2020, the available lending capacity of money market counterparties was estimated at 2,566.1 billion FCFA, well above the refinancing needs of the

\footnotetext{
3 System of Collection, Exploitation and Restitution to Banks and Financial Institutions of the CEMAC Regulatory States

${ }^{4}$ Based on Cerber System data from July 2020-June 2021

${ }^{5}$ Banks dependent on the BEAC refinancing were excluded from the main liquidity injection operation.
} 
banking system (BEAC, 2020h). The evaluation of these measures was set to expire in August 2021.

In July 2020, the MPC initiated the third measure, which consisted of implementing a programme of on-time and targeted repurchases of securities issued by the six member states on the secondary market to the sum of 600 billion FCFA (BEAC, 2020f). For the implementation of this programme, after the internal work, the BEAC proceeded to inform the various national monetary authorities and main actors of the money market regarding the existence of the programme as well as its modalities of implementation, in particular with regard to the primary dealers. ${ }^{6}$ To this effect, several workshops bringing together national treasuries and primary dealers (SVTs) were organised, with the secondary objective of extending this repurchase programme to securities already in the portfolio, while the treasuries expected direct advances that had been banned since the end of 2017.

Although other national treasuries have submitted applications for eligibility, it should be noted that this programme has been mostly carried by the National Treasury of Gabon, with the introduction in mid-November 2020 of three Fungible French Treasury bonds (OTAs) issued for a total amount of 72.5 billion FCFA for which the BEAC carried out repurchase operations up to 20.74 billion FCFA, an amount equivalent to the part not covered by the primary dealers. The repurchase prices varied between $88 \%$ and $95 \%$, corresponding to the rounded-up weighted average prices of the auctions (BEAC, 2021a; IMF, 2021). This buyback programme, whose initial duration was for 6 months, was extended twice for various reasons, including economic results in 2021. The next section focuses on targeted credit programmes put in place by the BEAC.

\section{Targeted credit programmes}

In this section, we provide a historical perspective of credit programmes in the BEAC, and this is followed by a discussion on the contemporary change in the BEAC's credit policy. We subsequently examine how the potential change in policy could emulate the effectiveness of mainstream central banks in monetary policy.

While the BEAC mandate was issued mainly to ensure price stability, the central bank has also involved financial stability as part of its monetary policy framework (Ngakosso,

\footnotetext{
${ }^{6}$ However, this invention by the BEAC remained subject to the following conditions: (i) at least $50 \%$ of the amount auctioned in each line must be subscribed by the SVTs; (ii) a minimum of three SVTs must participate in the auctions of the line of securities; and (iii) the Treasury must not reject more than $5 \%$ of the bids received from SVTs.
} 
2016). Moreover, in response to the COVID-19 pandemic, among other pressures, during a recent meeting at the BEAC in June 2021, it was established that the general policy orientation was to shift towards both price stability and economic growth (Nsangou, 2021).

In light of the above, contrary to the monetary policy backbone of the BEAC, which had been fundamentally articulated along the lines of fighting inflation and promoting financial stability, tailoring new policies towards promoting economic growth by means of targeted credit schemes will go a long way toward boosting socio-economic development in the CEMAC countries, not least because targeted credit programmes in many countries designed to fight the COVID-19 pandemic are a new phenomenon (Mosser, 2020). Hence, because the design of policies would be adapted to country-specific constraints, coupled with uncertainty about the effectiveness of these policies, it would be an opportunity for the BEAC to improve its monetary policy as opposed to its hitherto preference for financial stability. That said, the fact that the new strategic direction has been heavily influenced, motivated, and shaped by the COVID-19 crisis, as well as the relative effectiveness of more flexible central banks in implementing policies to hedge the potential risks associated with the crisis, is very reassuring.

Based on the discussion above, a policy orientation focusing more on economic growth and employment is consistent with policies adopted by other countries at the advent of the COVID-19 pandemic which were designed to provide financial bridges to the real economy, support households, preserve jobs, and keep firms solvent, among other goals (Mosser, 2020). Accordingly, the targeted lending policies are consistent with government fiscal policies designed to support firms and households, with the exception of the fact that in view of weathering the negative economic consequences from the pandemic, the new credit programmes should also be designed to lend to the government.

It is also worth emphasising some conditions necessary for a targeted credit programme to be effective (Mosser, 2020). First, a well-functioning corporate credit market is necessary, given that targeted central banks' credit programmes are designed to support the provision of credit to large corporations in a country and/or regions through expanded commercial paper and corporate bonds. Second, given that central banks do not directly target small businesses, it is necessary for commercial banks to make conditions for credit more inclusive, especially as it pertains to leveraging on the extensive margin theory designed to increase credit access to households, small businesses, and the previously unbanked population. In this direction, consolidating and empowering institutions that limit information asymmetry between lenders and borrowers in the banking industry is vital (Tchamyou \& 
Asongu, 2017; Tchamyou, 2019). Third, governments in the CEMAC zone need to adopt a common policy framework through which potential losses from the targeted credit programmes from the central bank are hedged. To put this in perspective, as documented by Mosser (2020), (i) the US Federal Reserve's targeting lending scheme would not have been possible without the US Congress allocating to the US Treasury about 450 billion USD for protection against potential losses by the US Federal Reserve; and (ii) in the UK, the Bank of England's lending programmefor large businesses is guaranteed up to of $80 \%$ by the UK government. The next section provides suggestions regarding the path forward.

\section{Suggestions regarding the path forward}

The way forward, as suggested by the IMF (2021), as a regional strategy that can be tailored to address the crisis, is apparent from five perspectives, namely: (i) fiscal consolidation efforts; (ii) monetary policy stance and operations;(iii) enforcement of foreign exchange regulations; (iv)financial sector reforms and policies; and (v) consolidating the CEMAC regional surveillance framework. These are policy insights that the BEAC monetary officials should bear in mind when designing and formulating policies in response to problems caused of the COVID-19 pandemic.

First, regarding fiscal consolidation efforts, it is worth noting that fiscal policy, especially within the remit of the COVID-19 pandemic, is designed to hedge against unfavourable ramifications to firms and households while at the same time, providing avenues for the sustainability of debt and external balances. With a $58 \%$ average public debt-to-GDP ratio in the CEMAC region, countries' fiscal policies should be tailored towards curbing public debt in the short-run to avoid high debt distress risks. Moreover, it is imperative that revenue mobilisation at the domestic level should be more effective in view of supporting external stability and preserving indispensable expenditures (IMF, 2021).

Second, in line with the IMF (2021), and within the remit of monetary policy stance and operations, monetary policy should be tailored to tackling concerns pertaining to the external positions of the CEMAC region, which are weak for the most part. Thus, monetary policy should adapt more to recovery - to ensure credibility and the stability of exchange rates - and liquidity management - in view of consolidating the transmission of monetary policy among other goals.

Third, monetary policy should also be tailored to enforcing exchange rate regulations as well as fast-tracking the repatriation of deposits that are held abroad. These measures, 
among others, should be consolidated with a specific emphasis on foreign exchange regulations associated with the extractive sector (IMF, 2021).

Fourth, within the framework of financial sector reforms and policies, monetary policy measures should go in tandem with enhanced transparency coupled with effective and timely communication on transparency-related concerns that can affect debt service, private domestic credit, and domestic investment as well as foreign exchange, reserves, and investment. In this direction, improving regulatory compliance and taking on board financial inclusion and transparency strategies are also necessary, and by extension, the framework for the CEMAC regional surveillance should also be enhanced (IMF, 2021).

In sum, in order for the BEAC to adequately formulate and implement policies that would boost regional development while addressing the COVID-19 crisis, the policy mix for the CEMAC region should be consistent with enhancing the region's external sustainability while giving priority to socio-economic needs (e.g., health and poverty concerns)that are immediately related to the pandemic. In essence, the regional strategy should be tailored towards a progressive and calculated restriction of monetary conditions so as to recover external reserves. Monetary policy should therefore be consistent with a fiscal policy which is designed to improve financial stability, while at the same making sure financial resources are available for a substantial vaccine rollout and support for those that are most vulnerable segments of the population. Ultimately, for the CEMAC region needs appropriate monetary and fiscal policies to weather the pandemic storm. Moreover, it is imperative for the region to continue on its path towards addressing fragilities in the financial sector while maintaining financial stability within the constraints of the pandemic.

\section{Conclusion and future research directions}

This study sheds light on the BEAC's responses to the COVID-19 pandemic. While hitherto the BEAC has largely focused on fighting inflation and promoting financial stability, the COVID-19 pandemic, as well as other factors, have motivated authorities of the central bank to adopt other measures such as targeted credit programmes. As noted in the study, there is a degree of socio-economic diversity in the CEMAC region. This socio-economic diversity means that the BEAC's responses to the pandemic would have different effects in the six countries which constitute the CEMAC region. Similar to central banks in other countries, we showed that the BEAC attempted to mitigate the economic impact of the COVID-19 
pandemic by implementing targeted credit programmes. These credit programmes were vital to the economies of the CEMAC countries.

That said, there are areas where more work needs to be done, for example, with respect to fiscal consolidation, monetary policy, enforcement of foreign exchange regulations, and financial sector reforms. Notably, the suggested reforms should be tailored in the direction of boosting inclusive growth and monitoring economic development at the regional level. To achieve sustainable development, structural reforms are required. This requires heavy lifting and political will. Regarding the monitoring of regional policies and socio-economic development, there is consensus from member countries for the following measures, among others, to be implemented: (i) prioritising strategies that improve the region's external sustainability and (ii) fast-tracking recent reforms and recovery programmes that were slowed by the COVID-19 pandemic.

In terms of caveats, it is obvious that the consequences of the pandemic will last longer than expected, especially as they relate to the economic growth potential of the CEMAC region. Accordingly, challenges in the long term are substantial, especially in relation to reinvigorating the economy and managing the huge structural variations resulting from the crisis. This is the reason the IMF (2021) also recommends regional authorities to engage in the process of gradual withdrawal of emergency measures that were taken when the pandemic started.

The findings in the study provide opportunities for future research, especially as further research is needed to understand more country-specific and regional-oriented policies that have been tailored to address the challenges of the COVID-19 pandemic. Accordingly, as more research on monetary concerns become apparent, comparative studies will also go a long way toward improving scholarly and policy perspectives. These future research directions are also motivated by the perspective that documented policy responses should not be blanket-type, but time-dynamic in the light of the evolving challenges the pandemic poses in the various CEMAC countries. These dynamic insights from central banks' policies should be understood within the remit of, among others, credit support and liquidity provision as well as other policy tools to stabilise the credit market and financial system, and by extension, provide support to the real economy. 


\section{References}

Abdel-Salam, O. H. (1970). "The Evolution of African Monetary Institutions" The Journal of Modern African Studies 8 (3): 339-362.

AfDB. (2021). Africa Economic Outlook 2021. African Development Bank, Abidjan.

AfDB. (2020). Africa Economic Outlook 2020. African Development Bank, Abidjan.

AfDB. (2018). Central Africa Economic Outlook 2018. Available online: https://www.afdb.org/fileadmin/uploads/afdb/Documents/Publications/2018AEO/AfricanEconomic-Outlook-2018-Central-Africa.pdf (accessed 20 July 2020)

AfDB. (2012). 'African Economic Outlook 2012: Promoting Youth Employment'. www.undp.org/content/dam/rba/docs/Reports/African\%20Economic\%20 Outlook\%202012\%20En.pdf (accessed 20 July 2020).

Asongu, S. A., (2014). "Does money matter in Africa? New empirics on long-and shortrun effects of monetary policy on output and prices", Indian Growth and Development Review, $7(2), 142-180$.

Asongu, S. A., (2016). "New empirics of monetary policy dynamics: evidence from the CFA franc zones", African Journal of Economic and Management Studies, 7(2), pp. 164-204.

Banque des États de l'Afrique Centrale (2021a), Lettre de la Recherche de la BEAC.

Banque des Etats de l'Afrique Centrale (2021b), Comité de politique monétaire, Décision $\mathrm{N}^{\circ} 01 / \mathrm{CPM} / 2021$, Febuary.

Banque des Etats de l'Afrique Centrale (2020a), Comité de politique monétaire, Décision $\mathrm{N}^{\circ} 01 / \mathrm{CPM} / 2020$, March.

Banque des Etats de l'Afrique Centrale (2020b), Comité de politique monétaire, Décision $\mathrm{N}^{\circ} 02 / \mathrm{CPM} / 2020$, March.

Banque des Etats de l'Afrique Centrale (2020c), Comité de politique monétaire, Décision $\mathrm{N}^{\circ} 03 / \mathrm{CPM} / 2020$, June.

Banque des Etats de l'Afrique Centrale (2020d), Comité de politique monétaire, Décision $\mathrm{N}^{\circ} 04 / \mathrm{CPM} / 2020$, June.

Banque des Etats de l'Afrique Centrale (2020f), Comité de politique monétaireDécision $\mathrm{N}^{\circ} 06 / \mathrm{CPM} / 2020$, July.

Banque des États de l'Afrique Centrale (2020g), bulletin du marchémonétaire $\mathrm{N}^{\circ} 313$, September.

Banque des États de l'Afrique Centrale (2020h), Lettre de la Recherche de la BEAC, December. 
Commission bancaire de l'Afrique centrale (COBAC). (2021). Système de Collecte, d'Exploitation et de Restitution aux Banques et établissements financiers des EtatsRéglementaires

Dzigbede, K.D. and Pathak, R. (2020), COVID-19 economic shocks and fiscal policy options for Ghana, Journal of Public Budgeting, Accounting \& Financial Management, Vol. 32 No. 5, pp. 903-917.

International Monetary Fund (2021), country Report on Central African Economic and Monetary Community, January.

de Zamaroczy, M., Fleuriet, V and Gijon, J. (2018). Central African Economic and Monetary Community: A New Medium-Term Approach for International Reserve Management. International Monetary Fund, Washington D.C.

Ejiogu, A., Okechukwu, O. \&Ejiogu, C. (2020). "Nigerian budgetary response to the COVID19 pandemic and its shrinking fiscal space: financial sustainability, employment, social inequality and business implications", Journal of Public Budgeting, Accounting \& Financial Management, 32(5), pp. 919-928.

Elgin, C., Yalaman, A., Yasar, S., \&Basbug, G., (2021). "Economic policy responses to the COVID-19 pandemic: The role of central bank independence", Economic Letters, 204(July), 109874.

Joseph, R. (1976). "The Gaullist Legacy: Patterns of French Neo-Colonialism". Review of African Political Economy, 3(6), pp. 4-13.

ILO. (2016). Transition vers le marché du travail des jeunes femmes et hommes enRépublique du Congo. Work4Youth Série de publication no. 39. ILO: Geneva. Available online: https://www.ilo.org/wcmsp5/groups/public/---

ed_emp/documents/publication/wcms_499741.pdf (accessed 22 July 2021)

International Monetary Fund (IMF). (2021). "Central African Economic and Monetary Community (CEMAC)” IMF Country Report No. 21/148, Washington, D.C.

International Monetary Fund (IMF).(2020). Chad: Requests for disbursement under the rapid credit facility, extension of the extended credit facility arrangement, and rephasing of access - press release; staff report; and statement by the executive director for Chad. IMF Country Report No. 20/134.International Monetary Fund: Washington, D.C.

International Monetary Fund(IMF). (2019). Gabon: Selected Issues. IMF Country Report No. 19/390. International Monetary Fund: Washington, D.C.

Masson, P\& Pattillo, C. (2004). The Monetary Geography of Africa. Brookings Institution Press: Washington, D.C.

Mosser, P. C. (2020). “Central bank responses to COVID-19”. Business Economics, 55(4), pp. 191- 201. 
Nchanji, E., Lutomia, C. K., Chirwa, R., Templer, N., Rubyogo, J. C., \& Onyango, P. (2021). "Immediate impacts of COVID-19 pandemic on bean value chain in selected countries in subSaharan Africa". Agricultural Systems, 188(March), 103034.

Ngakosso, A., (2016). Monetary Policy and Financial Stability: A CEMAC Zone Case Study.International Journal of Economics and Finance, 8(7), pp. 244-257.

NIS [National Institute of Statistics] (2015a). National Report on the Millennium Development Goals in 2015. Yaounde, CM: NIS.

NIS[National Institute of Statistics]. (2015b). Presentation of the First Results of the Fourth Cameroon Household Survey (ECAM) of 2014. Yaounde, CM: NIS.

Nsangou, P., (2021). "Conjecture économiqueen zone CEMAC : la Beacrevoitsesprévisions de croissance ", Cameroon Tribune, https://www.cameroon-tribune.cm/article.html/41029/fr.html/conjoncture-economique-enzone-cemac-la-beac-revoit-ses-previsions-de-croissance (Accessed: 19/08/2021).

Tchamyou, V. S., (2019). "The Role of Information Sharing in Modulating the Effect of Financial access on Inequality”. Journal of African Business, 20(3), pp. 317-338.

Tchamyou, V. S., \& Asongu, S. A., (2017). "Information Sharing and Financial Sector Development in Africa", Journal of African Business, 18(1), pp. 24-49.

United Nations Population Fund [UNFPA]. 2018. Equatorial Guinea 2018: Key Achievement Results as of December 2018. UNFPA. Available online: https://www.unfpa.org/sites/default/files/GQ_UNFPA_Results_07_27.pdf (accessed 22 July 2021)

Vinay, B. (1988). Zone Franc et Coopération Monétaire, second edition. Paris: Ministère dela Coopération et du Développement.

World Bank. 2021a. The World Bank in Chad. Available online: https://www.worldbank.org/en/country/chad/overview (accessed 22 July 2021)

World Bank. 2021b. The World Bank in Cameroon. Available online: www.worldbank.org/en/country/cameroon/overview (accessed 22 July 2021)

World Food Programme [WFP]. 2018. Rapport de l'examenstrategique national faimeroen Republic Centrafrique. World Food Programme. Available online: https://docs.wfp.org/api/documents/WFP-

0000104939/download/?_ga=2.150126582.1333983268.1626984189-433612495.1626984189

(accessed 22 July 2021) 